\title{
Switching at the cellular level in the white-opaque transition of Candida albicans
}

\author{
Marshall S. Bergen, Edward Voss and David R. Soll* \\ Department of Biology, University of Iowa, Iowa City, Iowa 52242, USA
}

(Received 26 March 1990; accepted 4 June 1990)

\begin{abstract}
The 'white-opaque transition' in Candida albicans strain WO-1 provides a unique system for analysing highfrequency switching at the cellular level because of the difference in the budding phenotypes of the white and opaque phases. Single white and opaque cells were placed on agar and monitored for the dynamics of cell division, microcolony genesis and switching to the alternative phase. It is demonstrated that at $24^{\circ} \mathrm{C}$, opaque cells can switch directly to white cells but white cells first generate an elongate, pseudohyphal-shaped precursor in the transition to an opaque cell. Cells in either phase can generate a daughter cell in the alternative phase, then revert immediately to the genesis of subsequent daughter cells in the original phase. By developing a mathematical model for switching at the cellular level which subtracts mother cells and switched daughter cells from the pool of switching candidates, the probability for an opaque cell to generate a white daughter cell in any single generation was calculated to be $1.0 \times 10^{-1}$, and the probability for a white cell to generate an opaque daughter cell in any single generation was calculated to be $1.7 \times 10^{-5}$ at $24^{\circ} \mathrm{C}$ on nutrient agar. The mean number of generations before an opaque cell generated a white daughter cell was calculated to be 3.4 and the mean number before a white cell formed an opaque cell was calculated to be 15.8 at $24{ }^{\circ} \mathrm{C}$ on nutrient agar. Finally, high-temperature induction of the opaque to white transition was analysed at the cellular level and demonstrated to involve frequent bipolar formation of white daughter cells on the original opaque mother cell, and in some cases intermediate phenotypes.
\end{abstract}

\section{Introduction}

Most strains of Candida albicans and the related species Candida tropicalis are capable of switching at high frequency between an apparently limited number of general phenotypes distinguishable by colony morphology (Slutsky et al., 1985, 1987; Pomes et al., 1987; Soll et al., 1987, 1988). The frequencies of switching have been indirectly determined by analyses of colony morphologies in clonal plating experiments (Slutsky et al., 1985, 1987; Anderson \& Soll, 1987), or in a more direct fashion in liquid microcultures by the Luria-Delbruck fluctuation formula (Rikkerink et al., 1988). However, switching has previously not been described at the cellular level. The 'white-opaque transition' in $C$. albicans strain WO-1 provides us with a unique opportunity to observe switching at the cellular level because of the distinct differences in cellular morphologies distinguishable by standard light microscopy (Slutsky $e t$ al., 1987; Anderson \& Soll, 1987; Anderson et al., 1989). In the white phase, budding cells are relatively round and resemble most $C$. albicans strains in the budding phenotype. In contrast, in the opaque phase, budding cells are elongate or bean-shaped, and roughly twice the volume of white cells (Slutsky et al., 1987). At the ultrastructural level, opaque cells differ from white cells in a number of characteristics, including the presence of a large vacuole filled with membranous or spaghetti-like material (Slutsky et al., 1987; Anderson et al., 1990), and opaque-specific cell-wall pimples (Anderson \& Soll, 1987; Anderson et al., 1989, 1990).

In the present study we have used the difference in shape of white and opaque cells to examine the cellular dynamics for a switch from white to opaque and from opaque to white, to estimate the probability of switching in both directions in microcolonies generated from single cells, and to visualize the transition from opaque to white after temperature induction. A mathematical model is developed to calculate probabilities of switching.

\section{Methods}

Maintenance of stock cultures of strain WO-1. C. albicans strain WO-1 was isolated from the blood and lungs of a bone-marrow transplant patient (Slutsky et al., 1987). Stock cultures of the strain were maintained on agar slants in capped tubes at room temperature. For 
experimental purposes, cells from the original stock slants were clonally plated on agar containing the defined nutrient medium of Lee $e t$ al. (1975) supplemented with $70 \mu \mathrm{g}$ arginine $\mathrm{ml}^{-1}$ and $0 \cdot 1 \mu \mathrm{M}-\mathrm{ZnSO}_{4}$ (Bedell \& Soll, 1979). White and opaque colonies were distinguished by colour and shape according to methods previously described (Slutsky $e t$ al., 1987).

Single cell analysis. Cells from a white or an opaque colony were removed by scraping a culture loop across the colony and spreading the cells on nutrient agar. Individual cells were then removed from the agar with a glass needle connected to a micromanipulator attached to the frame of a Zeiss microscope, and placed individually on nutrient agar either in a Petri dish or on a microscope slide. Cells and microcolonies were photographed on T-Max 100 film (Eastman Kodak) at time intervals with a Zeiss ICM 405 inverted microscope equipped with a green filter.

Switching frequency analysis. Opaque cells were removed from an opaque colony, diluted with distilled water to a concentration of $10^{3}$ c.f.u. $\mathrm{ml}^{-1}$, and $0.1 \mathrm{ml}$ cell suspension was spread in the centre of an agar plate. These cultures were incubated for 12 to $16 \mathrm{~h}$ at $24^{\circ} \mathrm{C}$, and each microcolony then scored for the number of white and the number of opaque cells. White cells were removed from a white colony, diluted with distilled water to a concentration of $10^{5}$ c.f.u. $\mathrm{ml}^{-1}$, and $0.1 \mathrm{ml}$ spread on an agar plate. These cultures were incubated for 17 to $20 \mathrm{~h}$ at $24^{\circ} \mathrm{C}$, and each microcolony then scored for the number of white and the number of opaque cells. When microcolonies grew beyond 50 cells, they were teased apart into groups containing 10 to 15 cells before counting cell types.

\section{Results}

The development of opaque or white microcolonies from single cells

To define the dynamics of cell division in the early genesis of an opaque colony at $25^{\circ} \mathrm{C}$, opaque cells were individually placed on nutrient agar. Examples of the division dynamics of two such cells are presented in Fig. 1 , in which the original mother cells are indicated with arrows. For the cell in Fig. 1(a), a half-grown daughter cell was evident at $3 \mathrm{~h}$ of incubation. At $5 \mathrm{~h}$ of incubation, a daughter cell was evident on the mother cell at the opposite pole, and the original daughter cell had formed an apical bud. The cell number doubled on average every $2 \mathrm{~h}$ between 3 and $14 \mathrm{~h}$ of incubation. As the microcolony developed, cells shifted so that little if any space was left in the colony proper. For the cell in Fig. 1 (b), roughly the same dynamics, including bipolar budding, were evident. In these two examples of opaque microcolony development, all divisions resulted in opaque cell phenotypes. The development of more than 100 opaque colonies from single opaque cells was monitored with similar results.

Examples of the division dynamics of two white cells placed on agar at $24^{\circ} \mathrm{C}$ are shown in Fig. 2, in which the original mother cells are again indicated with arrows.
For the cell in Fig. 2(a), a half-grown daughter cell was evident at $3 \mathrm{~h}$ of incubation. At $5 \mathrm{~h}$ of incubation, a daughter cell was evident on the mother cell, but at the same pole as the original daughter cell, and the original daughter cell had formed a bud. The cell number doubled on average every $2 \mathrm{~h}$ between 3 and $14 \mathrm{~h}$ of incubation. For the cell in Fig. 2(b), which already had a small bud at the time of isolation, roughly the same division dynamics were observed. Although white and opaque microcolonies divided at approximately the same rate and contained approximately the same number of cells after $14 \mathrm{~h}$, white cells never exhibited bipolar budding and white microcolonies were approximately half the diameter of opaque microcolonies, presumably a result of the smaller diameter of the component white cells (Slutsky et al., 1987). The development of more than 100 white colonies from single white cells was monitored with similar results.

\section{The transition from opaque to white at the single cell level}

To observe a switch from opaque to white at the cellular level, opaque cells (100 cells per experiment; three experiments) were plated on nutrient agar at $24^{\circ} \mathrm{C}$ and individually monitored for a spontaneous switch from opaque to white at the first evagination. The opaque cell in Fig. 3(a) already had a small round bud at the time of isolation. After $3 \mathrm{~h}$ of incubation, the daughter cell had expanded into a white cell, and a cluster of five additional white cells was localized at the original white daughter cell position. After $4.5 \mathrm{~h}$ of incubation, the microcolony consisted of roughly 13 white cells and the original opaque cell, representing a mean generation time of less than $2 \mathrm{~h}$. It should be noted that the opaque cell in Fig. 3(a) failed to release opaque daughter cells even though it was phenotypically opaque. No intermediate phenotype was evident in the opaque to white transition at $24^{\circ} \mathrm{C}$, and all progeny in the microcolony at $9 \mathrm{~h}$ exhibited the small, round, white phenotype. Twenty-six switches from opaque to white were observed with similar dynamics.

In two cases, an opaque cell gave rise to both white and opaque daughter cells. In Fig. 3(b), the isolated opaque cell formed a white bud by $6 \mathrm{~h}$ of incubation. At $7.5 \mathrm{~h}$ of incubation, it had formed an opaque daughter cell at the same time that the white daughter cell had formed a white bud. At $9 \mathrm{~h}$ of incubation, the microcolony consisted of half white cells and half opaque cells. This scenario demonstrates that an opaque cell can generate a white daughter cell, then revert to the genesis of an opaque daughter cell. Again no intermediate phenotype was evident in the opaque to white switch. 

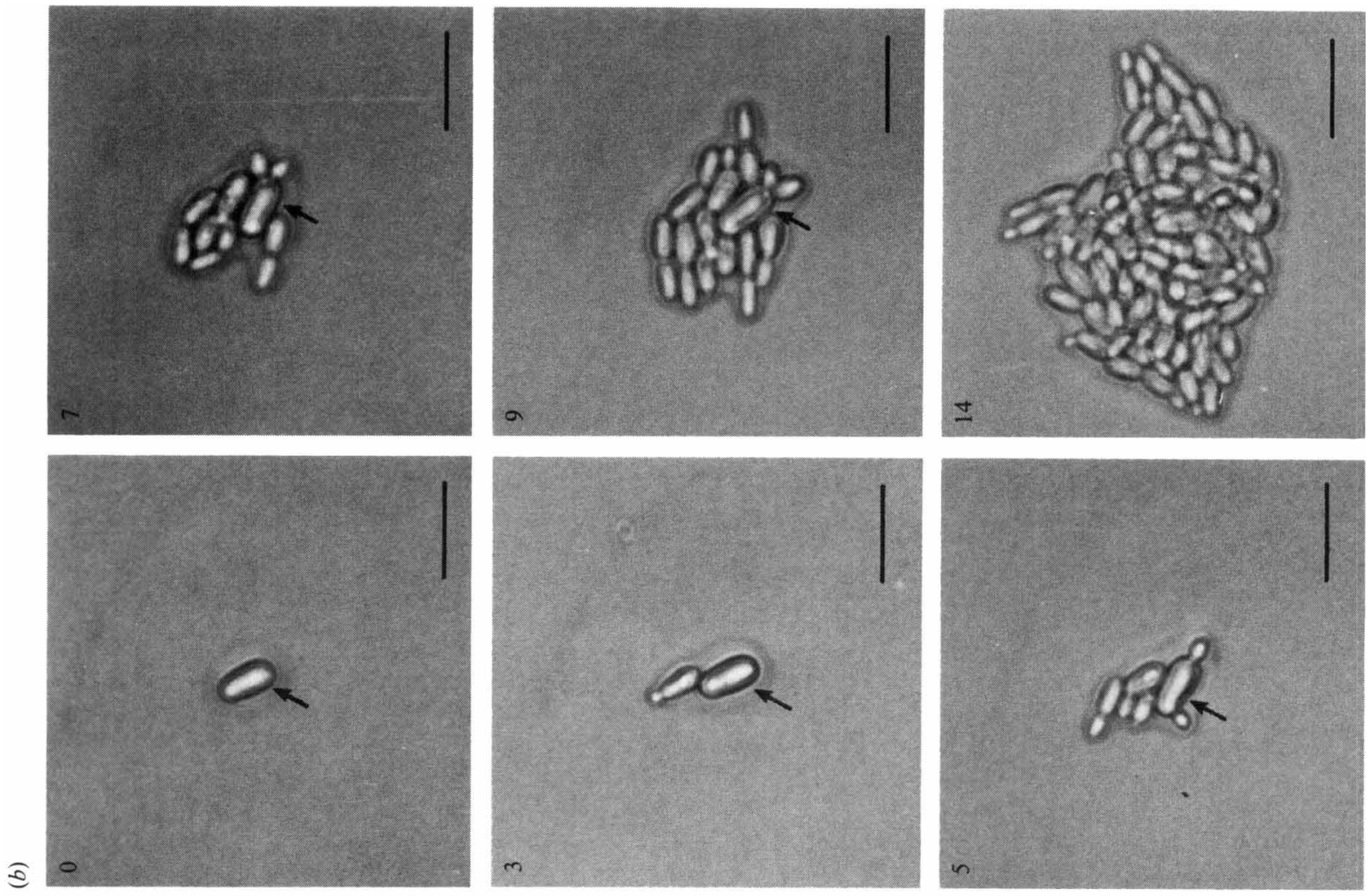

总
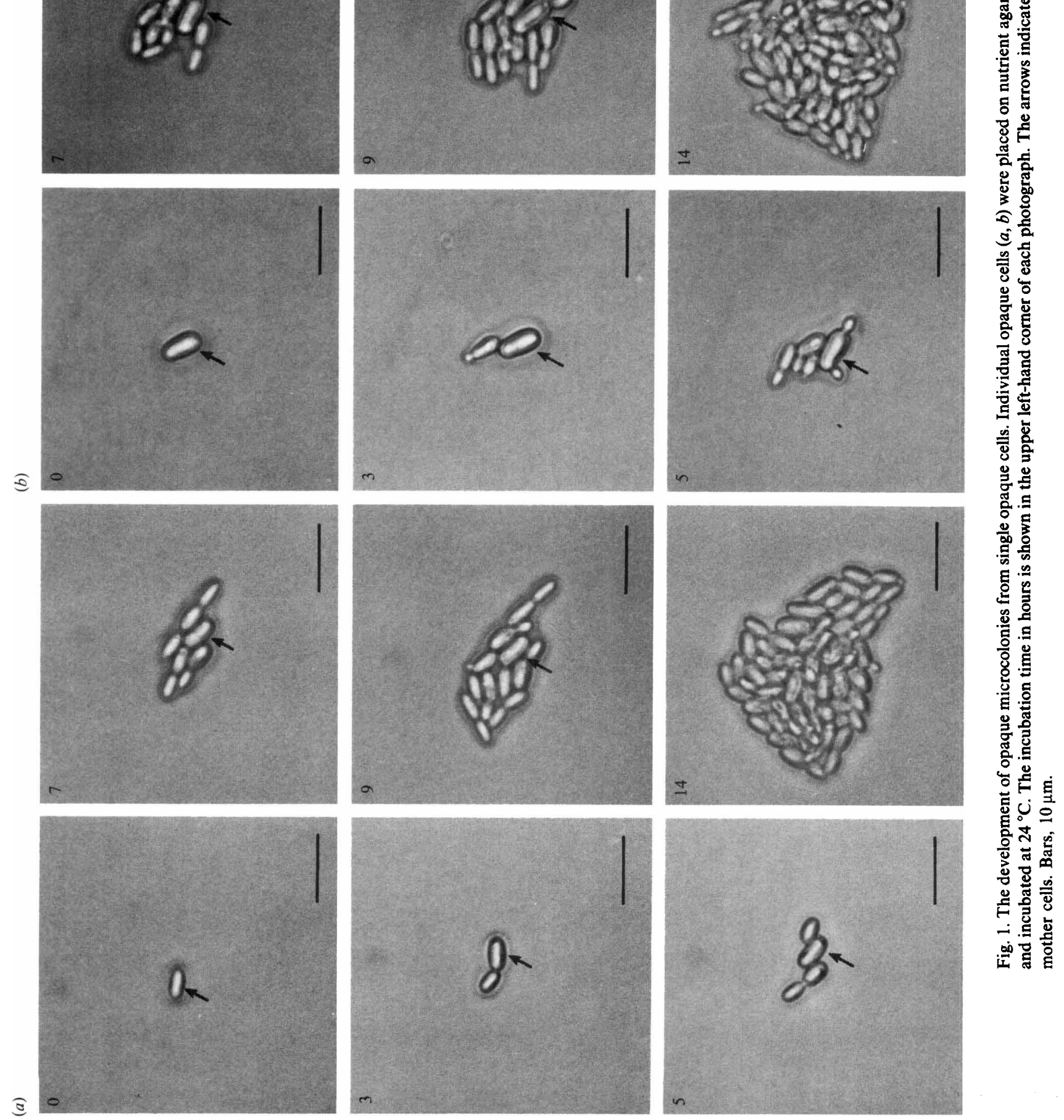

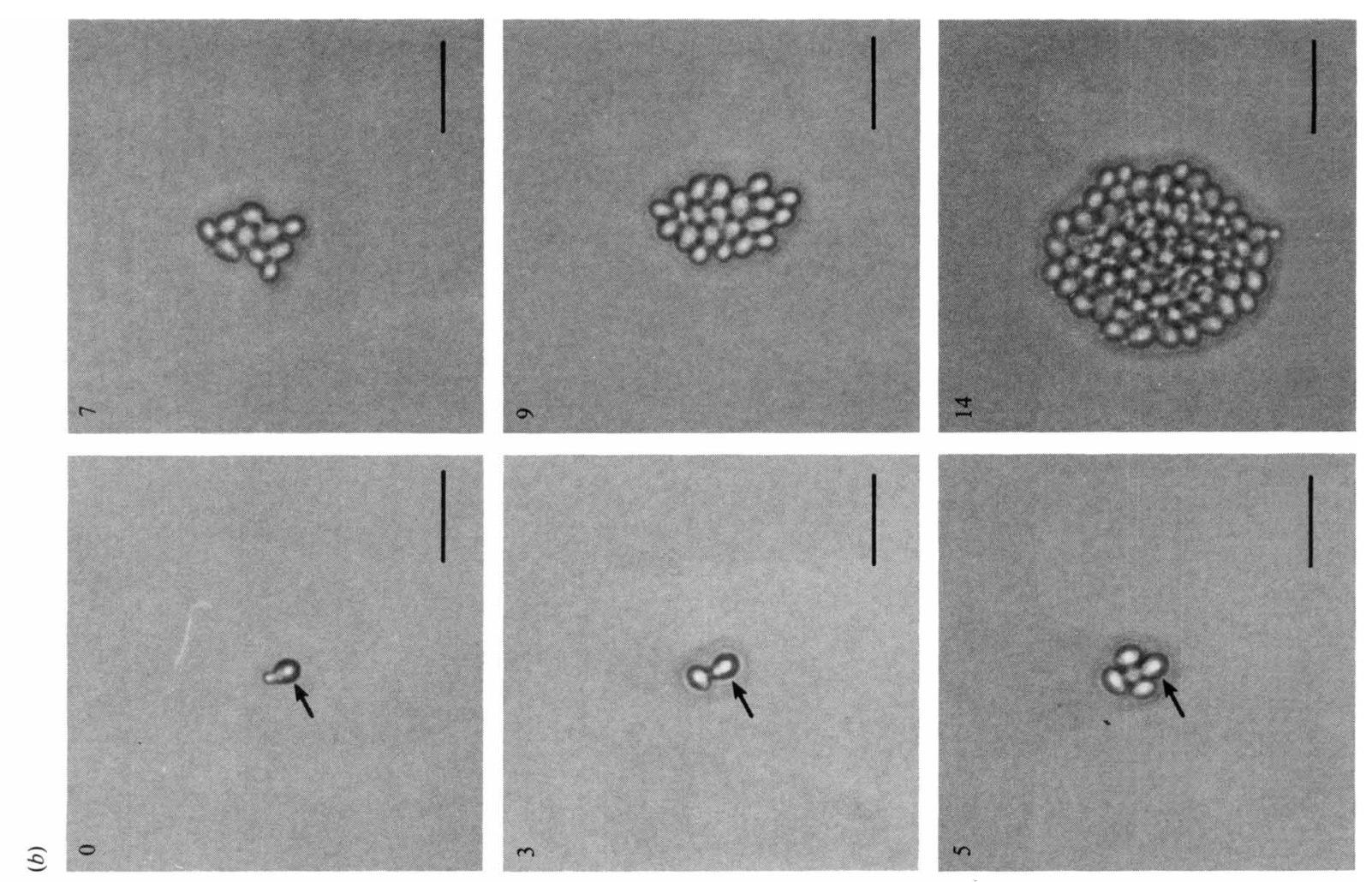

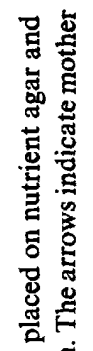
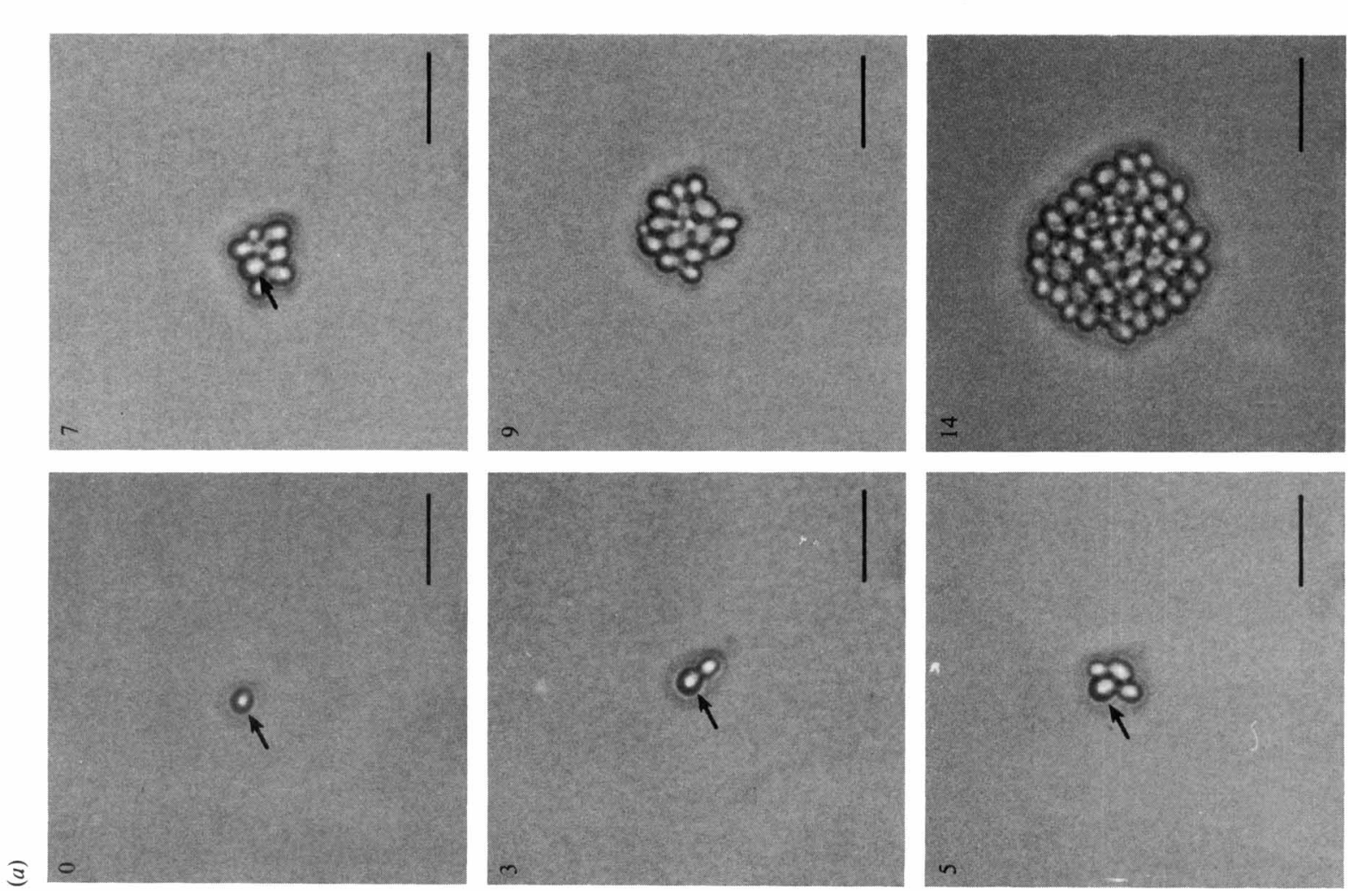

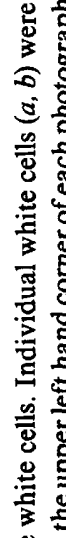

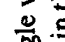

焉

옹

政

홍

.

.

है

产

है

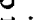

政

㩆

递家

要要

焉密

送总 


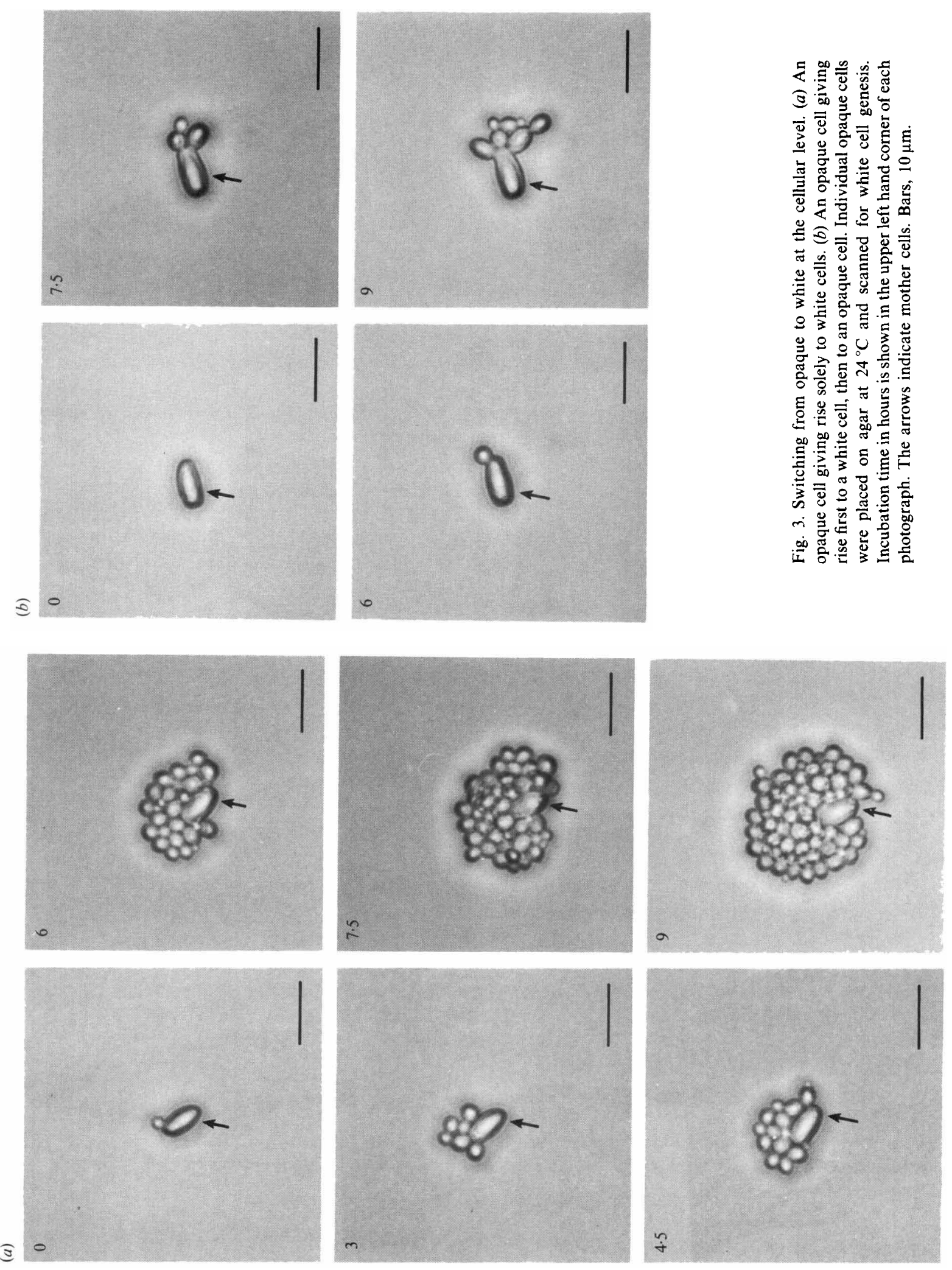


1930 M. S. Bergen, E. Voss and D. R. Soll

(a)
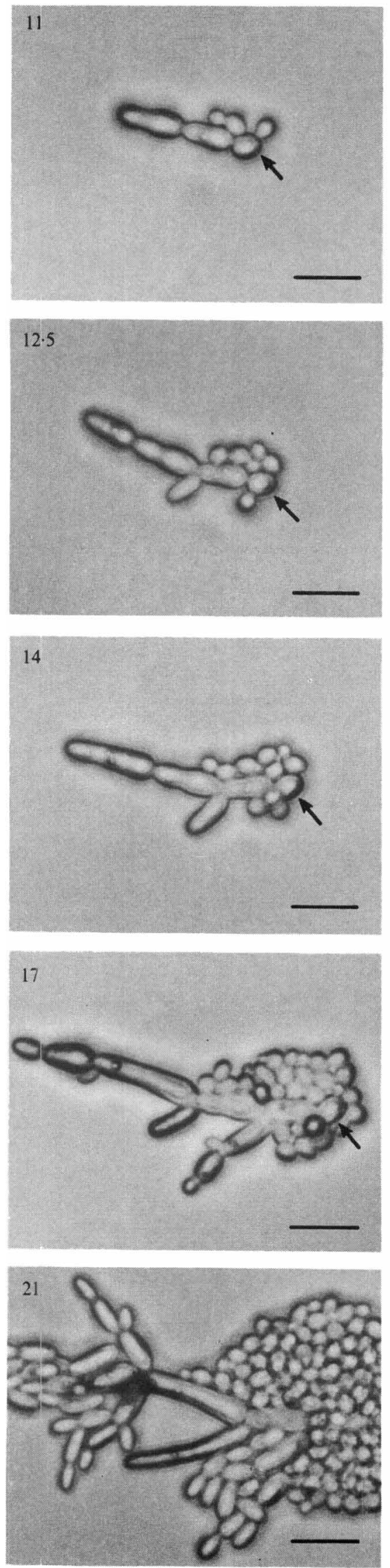

(b)
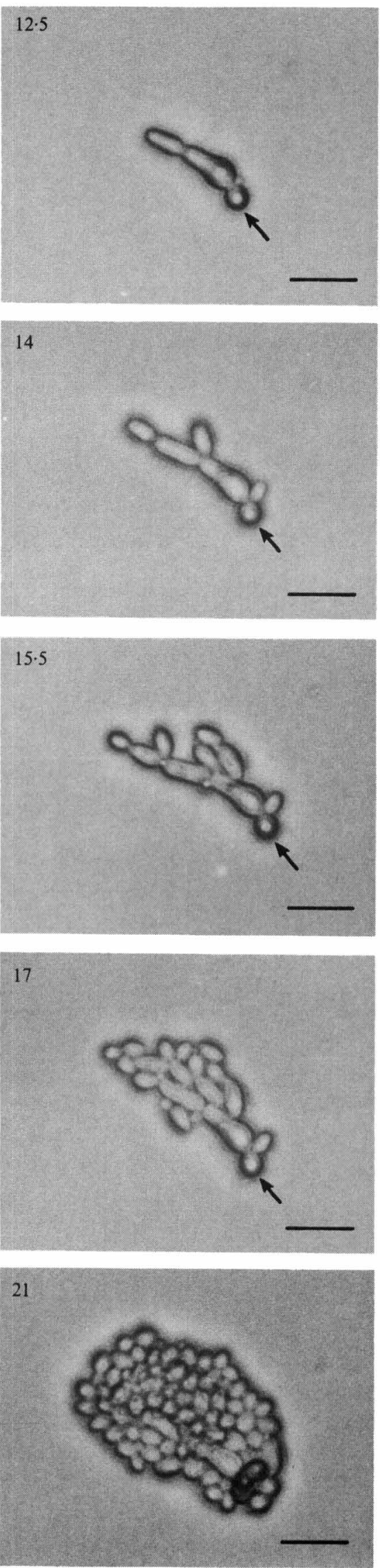

(c)
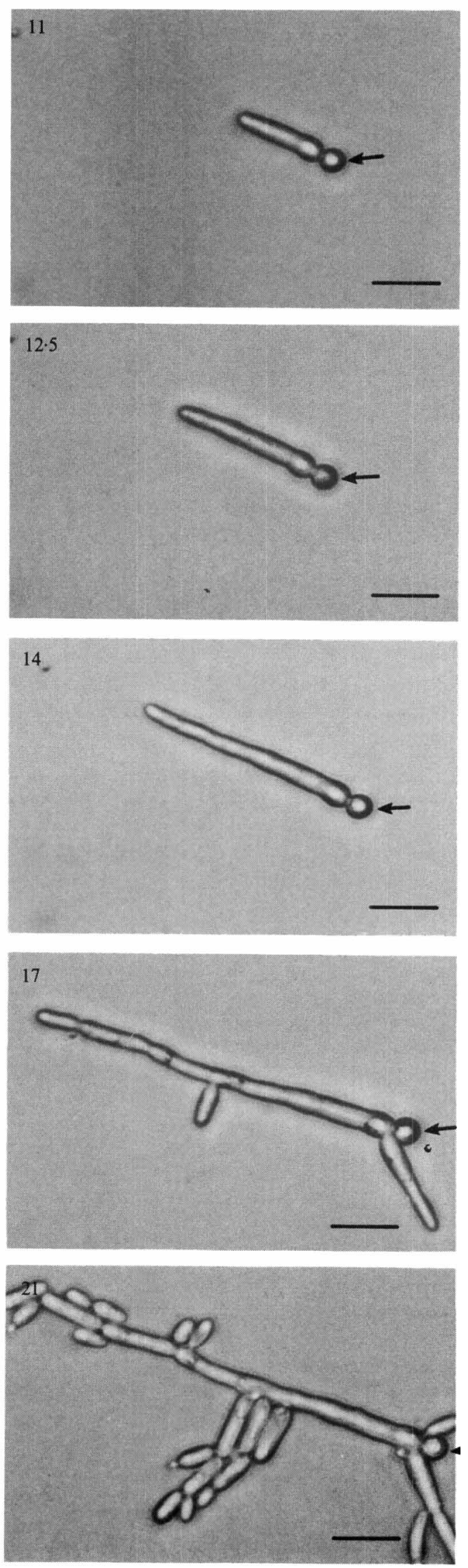
The transition from white to opaque at the single cell level

Far fewer examples of white cells forming opaque daughter cells were observed at the single cell level since it has been demonstrated to be a far rarer event (Rikkerink et al., 1988; also, see later section on switching frequencies). To observe a switch in the white to opaque direction, 10000 cells were placed on nutrient agar in each of five experiments and monitored for opaque cell formation. The white cell in Fig. 4(a) had already generated an elongate, pseudohyphal-shaped cell which in turn had formed a second elongate cell by $11 \mathrm{~h}$ of incubation. These daughter cells were far more elongate than opaque cells and were bulbous at their base (compare elongate daughter cells in Fig. 4(a) with standard opaque cell morphology in Fig. 1). The shapes of these intermediate cell types were similar to white cells which have been induced to form a hypha early in the budding cycle (Buffo et al., 1984; Soll et al., 1985): relatively round at the position of the original daughter bud and tapering apically into a hyphal or pseudohyphal form (Soll et al., 1985). In addition to the elongate daughter cell, the mother cell in Fig. 4(a) had also generated two white daughter cells by $11 \mathrm{~h}$. The elongate progeny continued to generate elongate, pseudohyphalshaped cells until $17 \mathrm{~h}$. After $17 \mathrm{~h}$, opaque cells formed apically and laterally from the original elongate daughter cells. By $21 \mathrm{~h}$, the microcolony consisted of a tightly packed white sector and a less tightly packed opaque sector emanating from the original, branched cells. The formation of an elongate, pseudohyphal-shaped daughter cell prior to opaque cell formation was observed in 21 cases for switches from the white to opaque phenotype.

The white cell in Fig. 4(b) had already generated an elongate daughter cell with an apically tapered phenotype which in turn had generated an opaque-shaped daughter cell by $12.5 \mathrm{~h}$ of incubation. The original elongate cell gave rise to one or more daughter cells with apparently the opaque phenotype, but the phenotype of all subsequent progeny was white. Additional daughter cells generated by the white cells were also white. By $21 \mathrm{~h}$, the microcolony consisted of an apparently opaque cell core with a majority of peripheral white cells.

The white cell in Fig. 4(c) had already generated an elongate tapered cell by $11 \mathrm{~h}$ of incubation. This daughter cell continued to grow as a relatively wide hypha until $14 \mathrm{~h}$ of incubation. After $17 \mathrm{~h}$ of incubation, opaque cells were generated laterally and apically from the original hypha.

\section{Switching frequencies measured in microcolonies}

The capacity to distinguish between white and opaque cell phenotype at the cellular level provided us with a method for estimating switching frequencies in microcolonies. Individual cells were plated on nutrient agar and incubated for 12 to $24 \mathrm{~h}$ at $24^{\circ} \mathrm{C}$. Each microcolony was then scored for the number of white and opaque cells.

In Table $1(a)$, results are presented for switching from opaque to white in opaque microcolonies. Seven individual experiments were done in which a total of 645 microcolonies, including 9624 cells, were scored. The average colony contained 16 cells. The frequency of a colony containing or more more white cells was $2.5 \times$ $10^{-1}$. The proportion of white cells in all cells scored was $1.2 \times 10^{-1}$.

In Table $1(b)$, results are presented for switching from white to opaque. Ten individual experiments were done in which a total of 17441 microcolonies, including 2083160 cells, were scored. The average colony contained 119 cells. Microcolonies larger than 50 cells were teased apart into groups of 10 to 15 cells before cells were scored for phenotype. The frequency of a colony containing one or more opaque cells was $4.4 \times 10^{-3}$. The number of cells exhibiting the intermediate, pseudohyphal phenotype ranged between one and three in colonies containing a switch. These intermediate cell types were not scored as either white or opaque. The proportion of opaque cells for all cells scored was $5.3 \times 10^{-4}$. These results demonstrate that the frequency of switching from opaque to white is far greater than that from white to opaque in microcolonies on defined nutrient agar at $24^{\circ} \mathrm{C}$.

\section{Mathematical model for determining the probability of switching and estimating the mean number of generations preceding a switch}

To determine the probability of a switch from one phase (A) to the other (B) at the cellular level, a mathematical model was developed. The assumptions of the model are that at $24^{\circ} \mathrm{C}$ (1) the mother cell (exhibiting the phenotype of phase A) itself cannot change its phenotype (change its shape to phase B), (2) when a daughter cell expresses the alternative phenotype (phase B), all progeny will show the switched phenotype (phase B), and (3) each daughter cell has a probability of expressing the alternative phenotype (phase B) when formed. At generation 0 , there are $M$ mother cells (in phase A). At

Fig. 4. Switching from white to opaque at the cellular level. Individual white cells were placed on agar at $24^{\circ} \mathrm{C}$ and scanned for opaque cell genesis. (a) A white cell giving rise to elongate cells which in turn give rise to an opaque cell sector (note that the white cell continues to give rise to white cells, which form a white cell sector); $(b)$ a white cell which gives rise to elongate cells which in turn give rise to opaque cells which rapidly revert to white cells; $(c)$ a white cell which gives rise to a hypha which in turn gives rise to opaque cells. Bars, $10 \mu \mathrm{m}$. 
Table 1. Switching frequencies and the calculated probability of switching in the opaque to white and white to opaque direction determined from the phenotypic composition of microcolonies

Formulae for the weighted means $\alpha_{\operatorname{Exp}}$ and $\alpha_{M}$ are derived in the text.

(a) Opaque to white transition

\begin{tabular}{|c|c|c|c|c|c|c|c|c|}
\hline Experiment & $\begin{array}{l}\text { Incubation } \\
\text { time (h) }\end{array}$ & $\begin{array}{c}\text { No. of } \\
\text { microcolonies }\end{array}$ & $\begin{array}{c}\text { Total } \\
\text { no. of cells }\end{array}$ & $\begin{array}{l}\text { No. of white } \\
\text { cells }\end{array}$ & $\begin{array}{l}\text { Proportion of } \\
\text { white cells }\end{array}$ & $\begin{array}{l}\text { Proportion of } \\
\text { colonies with } \\
\text { one or more } \\
\text { white cells }\end{array}$ & $\begin{array}{c}\text { Weighted mean } \\
\alpha_{\text {Exp for }} \\
\text { each experiment }\end{array}$ & $\begin{array}{c}\text { Weighted mean } \\
\alpha_{\text {Exp }} \times \text { total } \\
\text { no. of cells }\end{array}$ \\
\hline 1 & 14 & 105 & 930 & 71 & $7.6 \times 10^{-2}$ & $1.6 \times 10^{-1}$ & $8.8 \times 10^{-2}$ & 81.8 \\
\hline 2 & 17 & 86 & 2004 & 31 & $1.5 \times 10^{-2}$ & $9.0 \times 10^{-2}$ & $5.4 \times 10^{-3}$ & 10.8 \\
\hline 3 & 16 & 82 & 1504 & 298 & $2.0 \times 10^{-1}$ & $3.1 \times 10^{-1}$ & $1.8 \times 10^{-1}$ & 270.7 \\
\hline 4 & 12 & 89 & 656 & 92 & $1.4 \times 10^{-1}$ & $2.4 \times 10^{-1}$ & $1.8 \times 10^{-1}$ & $118 \cdot 1$ \\
\hline 5 & 15 & 94 & 1354 & 304 & $2.2 \times 10^{-1}$ & $2.5 \times 10^{-1}$ & $1.8 \times 10^{-1}$ & 243.7 \\
\hline 6 & 13 & 97 & 1510 & 233 & $1.5 \times 10^{-1}$ & $3.7 \times 10^{-1}$ & $1.1 \times 10^{-1}$ & $166 \cdot 1$ \\
\hline \multirow[t]{2}{*}{7} & 12 & 92 & 1666 & 119 & $7.0 \times 10^{-2}$ & $3.0 \times 10^{-1}$ & $6.1 \times 10^{-2}$ & 101.6 \\
\hline & & ls: 645 & 9624 & Me: & $: 1.2 \times 10^{-1}$ & $2.5 \times 10^{-1}$ & & Total: 992.8 \\
\hline
\end{tabular}

Probability of a switch from opaque to white $\left(\alpha_{M}\right)=992.8 / 9624=1.0 \times 10^{-1}$

(b) White to opaque transition

\begin{tabular}{|c|c|c|c|c|c|c|c|c|}
\hline Experiment & $\begin{array}{l}\text { Incubation } \\
\text { time (h) }\end{array}$ & $\begin{array}{c}\text { No. of } \\
\text { microcolonies }\end{array}$ & $\begin{array}{c}\text { Total } \\
\text { no. of cells }\end{array}$ & $\begin{array}{l}\text { No. of opaque } \\
\text { cells }\end{array}$ & $\begin{array}{l}\text { Proportion of } \\
\text { opaque cells }\end{array}$ & $\begin{array}{l}\text { Proportion of } \\
\text { colonies with } \\
\text { one or more } \\
\text { opaque cells }\end{array}$ & $\begin{array}{l}\text { Weighted mean } \\
\alpha_{\text {Exp for }} \\
\text { each experiment }\end{array}$ & $\begin{array}{c}\text { Weighted mean } \\
\alpha_{\operatorname{Exp}} \times \text { total } \\
\text { no. of cells }\end{array}$ \\
\hline 1 & 19 & 127 & 18790 & 3 & $1.6 \times 10^{-4}$ & $2 \times 10^{-2}$ & $7 \cdot 1 \times 10^{-5}$ & $1 \cdot 3$ \\
\hline 2 & 17 & 136 & 14552 & 3 & $2.0 \times 10^{-4}$ & $7 \times 10^{-3}$ & $6.2 \times 10^{-5}$ & $9 \cdot 0$ \\
\hline 3 & 17 & 94 & 2430 & 4 & $1.6 \times 10^{-3}$ & $1 \times 10^{-2}$ & $7.4 \times 10^{-4}$ & 1.8 \\
\hline 4 & 19 & 119 & 6307 & 0 & - & - & - & - \\
\hline 5 & 18 & 109 & 4796 & 0 & - & - & - & - \\
\hline 6 & 24 & 63 & 6300 & o & - & - & - & - \\
\hline 7 & 17 & 177 & 6372 & 21 & $3.3 \times 10^{-3}$ & $6 \times 10^{-3}$ & $1.8 \times 10^{-3}$ & $11 \cdot 2$ \\
\hline 8 & 20 & 116 & 6380 & 0 & - & - & - & - \\
\hline 9 & 17 & 9200 & 1343200 & 20 & $1.5 \times 10^{-5}$ & $4.4 \times 10^{-4}$ & $4.2 \times 10^{-6}$ & $5 \cdot 6$ \\
\hline \multirow[t]{2}{*}{10} & 17 & 7300 & 674033 & 21 & $3.1 \times 10^{-5}$ & $8.2 \times 10^{-4}$ & $9.9 \times 10^{-6}$ & $6 \cdot 6$ \\
\hline & & tals: 17441 & 2083160 & Mea & $5.3 \times 10^{-4}$ & $4.4 \times 10^{-3}$ & & Total: 35.5 \\
\hline
\end{tabular}

Probability of a switch from white to opaque $\left(\alpha_{M}\right)=35.5 / 2083160=1.7 \times 10^{-5}$

generation 1 , each mother cell produces a daughter cell with a probability $\alpha$ of expressing the phenotype of phase $B$. The number of daughter cells expressing phase $B$ will therefore be $\alpha M$ and the number of unswitched daughter cells (in phase A) will be $\beta M$, where $\beta=1-\alpha$. After generation 1 , the number of unswitched cells (in phase A) is $M+\beta M$, or $(1+\beta) M$ out of a total cell population of $2 M$. Therefore, the population after generation 1 contains $M+\beta M$ mother cells in phase $\mathrm{A}$ which are capable of generating a daughter cell in phase B with a probability of $\alpha$. After generation 2, each of the $2 M$ cells in the population generates a daughter, yielding (2) (2M) cells, or $2^{2} M$ cells. The number of unswitched cells (in phase A) in generation 2 is the original number of mother cells plus the number of unswitched daughter cells:

$$
[(1+\beta) M]+\beta[(1+\beta) M]=(1+\beta)^{2} M
$$

Continuing in this manner, the number of unswitched cells (in phase A) after $K$ generations is $(1+\beta)^{K} M$, and the number of switched cells (in phase B):

$$
\left[2^{K}-(1+\beta)^{K}\right] M
$$

Experimentally, the following can be determined: $M$, the original number of cells (in phase A); $T$, the final number of cells (in phase $\mathrm{A}$ and $\mathrm{B}$ ); and $S$, the final number of switched cells (in phase B). Since $T=2^{K} M$, the number of generations can be determined by the formula:

$$
K=\frac{\ln T-\ln M}{\ln 2}
$$

Once $K$ is calculated, $\beta$ can be determined by the formula:

$$
\beta=\left(\frac{T-S}{M}\right)^{1 / K}-1
$$

Since $\alpha=1-\beta, \alpha$ can be determined by the formula:

$$
\alpha=2-\left(\frac{T-S}{M}\right)^{1 / K}
$$


In each experiment, $T, \alpha$ and $\beta$ were calculated for each microcolony. In a single experiment in which a number of microcolonies were analysed, the mean probability for the experiment, $\alpha_{E x p}$, was calculated from individual $\alpha$ values weighted for final microcolony size (i.e. final number of cells in each microcolony). The formula for $\alpha_{\mathrm{Exp}}$ was:

$$
\alpha_{\mathrm{Exp}}=\frac{\alpha_{1} T_{1}+\ldots+\alpha_{n} T_{n}}{T_{1}+\ldots+T_{n}}
$$

where $n$ is the number of microcolonies, $\alpha_{i}(1 \leqslant i \leqslant n)$ is the probability of switching in each microcolony, and $T_{\mathrm{i}}$ $(1 \leqslant i \leqslant n)$ is the final number of cells in each microcolony. Finally, the mean probability $\alpha_{M}$ for a number of experiments was determined by computing a weighted mean of the $\alpha_{\mathrm{Exp}}$ values using the final number of cells in each experiment as the weights. The computations of $\alpha_{M}$ for opaque to white from the seven independent experiments done, and for white to opaque from the 10 independent experiments done, are presented in Table 1. The probability, $\alpha_{M}$, for an opaque to white switch was calculated to be $1.0 \times 10^{-1}$, and for a white to opaque switch $1.7 \times 10^{-5}$.

The probability $\alpha$ can now be used to estimate the mean number of generations preceding a switch. Beginning with a single mother cell, the number of potential switch events, $E$, required to produce a single switch must satisfy the following equation:

$$
\alpha E=1
$$

Therefore, on average $1 / \alpha$ potential switch events must occur before the first switch. To determine the number of generations, $K$, required to give $1 / \alpha$ potential switch events, consider the following family tree in which we assume no switches have yet occurred (Fig. 5). As the result of a division, the cell on the right is always considered the potentially switched daughter cell $(X$ marks the potential switch event). Up to generation $K$, there are

$$
2^{0}+2^{1}+\ldots+2^{K-1}=2^{K}-1
$$

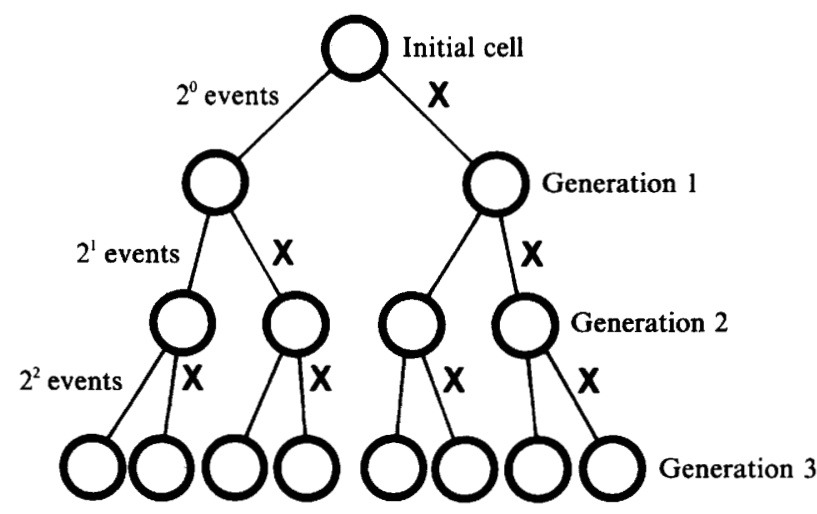

potential switch events. Hence:

$$
2^{K}-1=1 / \alpha, \text { and } K=\frac{\ln (1 / \alpha+1)}{\ln 2}
$$

where $K$ is the expected number of generations before the first switch. Using this formula, the expected number of generations before an opaque cell switches was calculated to be 3.4, and the expected number of generations before a white cell switches was calculated to be 15.8 at $24^{\circ} \mathrm{C}$.

\section{An analysis of temperature-stimulated switching at the cellular level}

Rikkerink et al. (1988) demonstrated that incubation of opaque cells in nutrient broth for at least $5 \mathrm{~h}$ stimulated mass conversion to white colony-forming units. To examine temperature-induced switching at the cellular level, we first tested whether opaque cells incubated individually on agar at $37^{\circ} \mathrm{C}$ also mass converted to white cell formation. Sixty individual opaque cells were incubated on agar at $24^{\circ} \mathrm{C}$ and sixty on agar at $37^{\circ} \mathrm{C}$ for $24 \mathrm{~h}$. All of the 56 colonies generated at $24^{\circ} \mathrm{C}$ (four original cells did not divide) were opaque and all of the 57 colonies generated at $37^{\circ} \mathrm{C}$ (three original cells did not divide) were white. When 30 cells from 15 colonies generated at $24^{\circ} \mathrm{C}$ were in turn plated at $24^{\circ} \mathrm{C}$, they generated opaque colonies, and when 30 cells from 15 colonies generated at $37^{\circ} \mathrm{C}$ were in turn plated at $24^{\circ} \mathrm{C}$, the subsequent colonies remained white. Therefore, incubation at $37^{\circ} \mathrm{C}$ also stimulated switching en masse from opaque to white.

To test whether temperature stimulation of the opaque-white transition on agar exhibited the lag period of roughly $5 \mathrm{~h}$ demonstrated in liquid culture (Rikkerink et al., 1988), opaque cells were individually plated at $37^{\circ} \mathrm{C}$ on nutrient agar, and at time intervals, cells from the developing microcolonies were separated by micromanipulation, incubated at $24^{\circ} \mathrm{C}$ for $42 \mathrm{~h}$, and the resulting microcolonies scored for phenotype. The results
Fig. 5. Family tree for determining the number of generations, $K$, required for $1 / \alpha$ potential switch events. As division occurs, the cell on the right is always considered the potentially switched daughter cell (X marks the potential switch event), and the cell on the left is always considered the mother cell. 

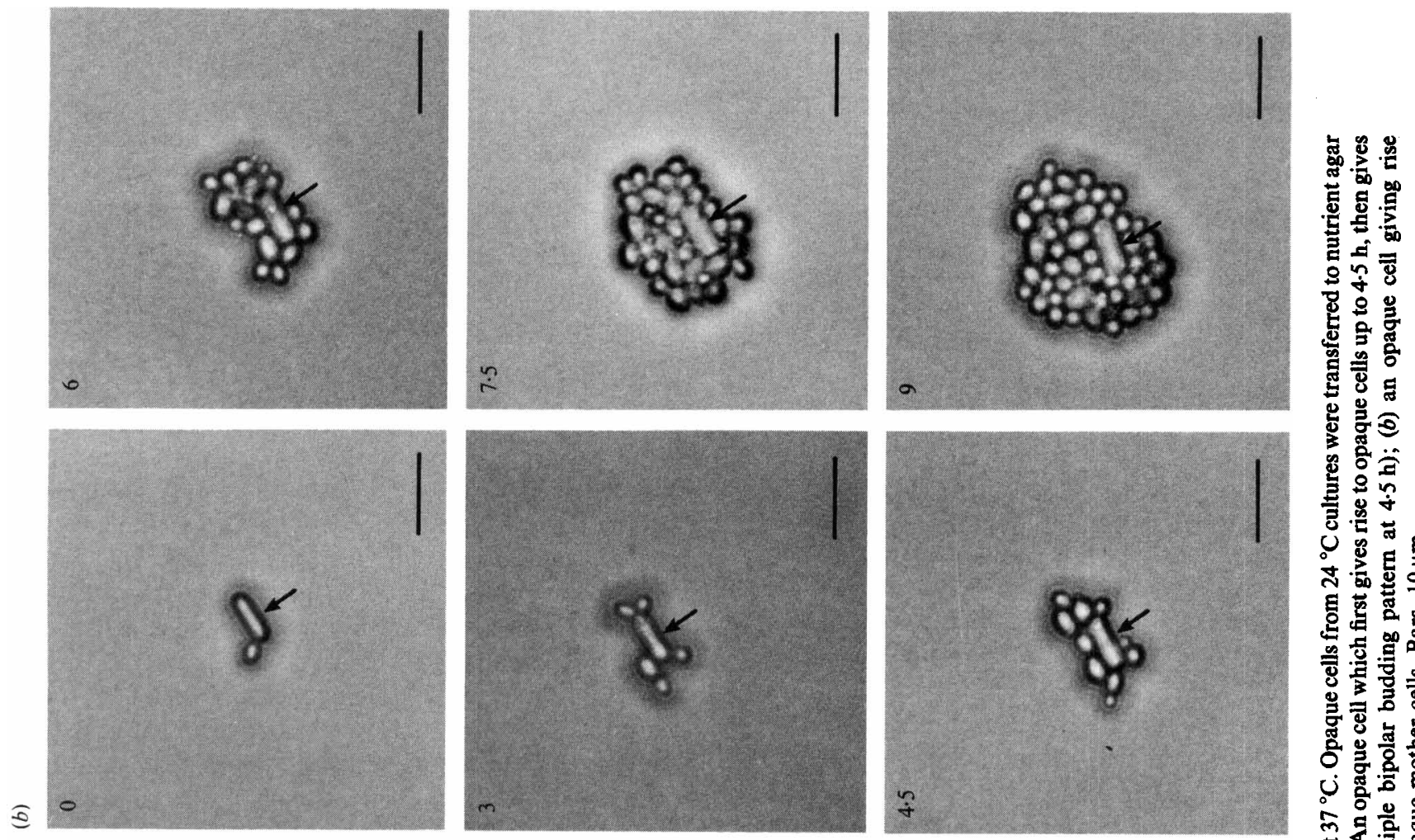

造娄

施

过运

訆兽

记

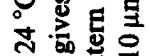

홍

要

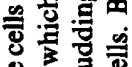

要

要

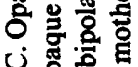

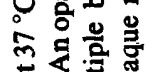
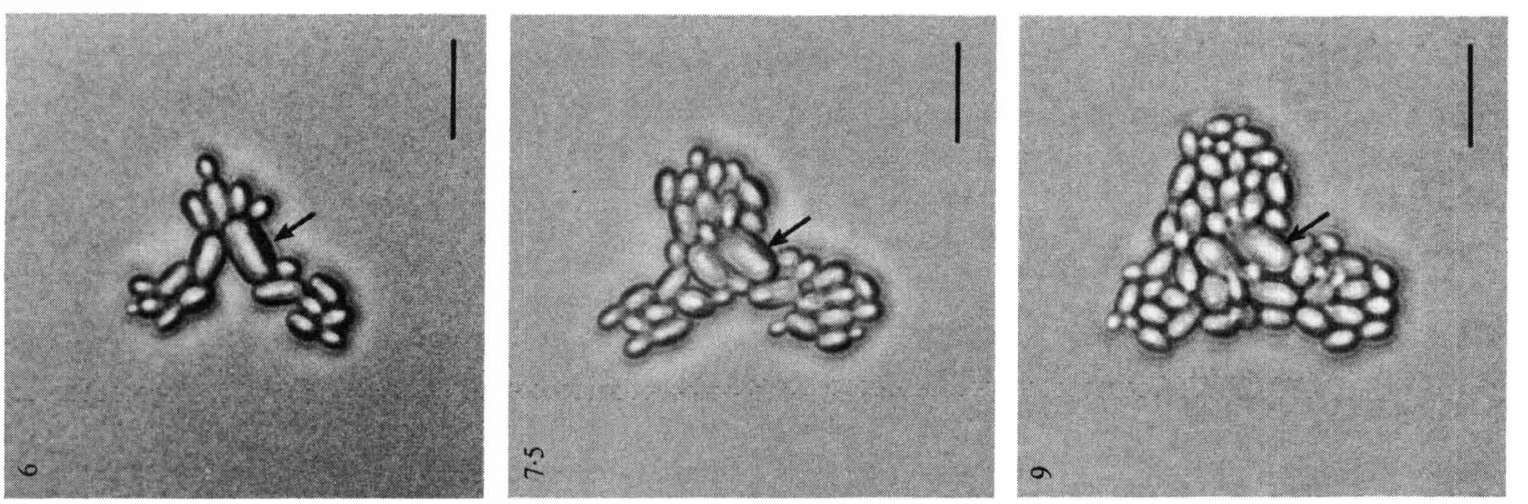

可司

政西

.

跣

要

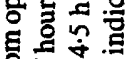

인

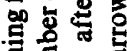

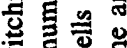

政

政

乎

马 क

范

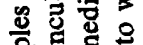

贻
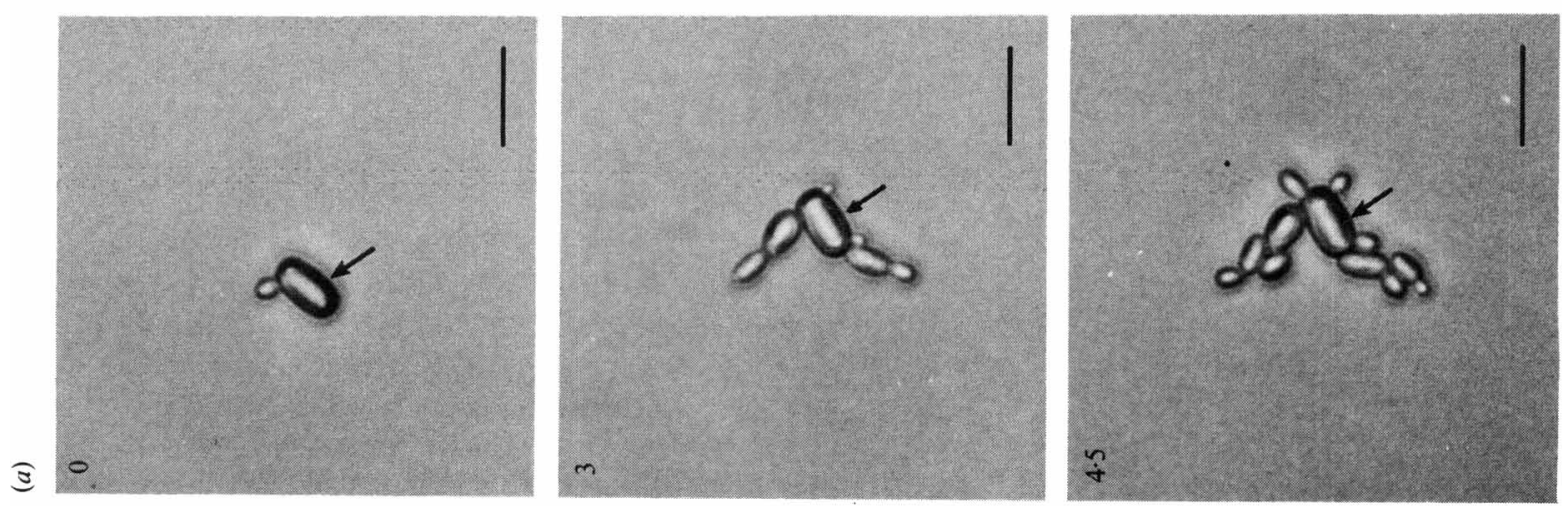

気惑

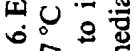

我总总具 
on agar were similar to those obtained in liquid culture (Rikkerink et al., 1988). When opaque cells were incubated for less than $5 \mathrm{~h}$ at $37^{\circ} \mathrm{C}$, the majority of cells removed from the microcolonies formed opaque colonies at $24{ }^{\circ} \mathrm{C}$. However, after $6 \mathrm{~h}$ of incubation at $37^{\circ} \mathrm{C}, 60 \%$ of the cells formed opaque colonies and $40 \%$ white colonies, and after $7 \mathrm{~h}, 100 \%$ of the cells formed white colonies.

In Fig. 6, examples are presented of the most common pattern of individual opaque cells switching to white after a shift from $24^{\circ} \mathrm{C}$ to $37^{\circ} \mathrm{C}$. In Fig. $6(a)$, the cell had already evaginated at the time of isolation. By $3 \mathrm{~h}$, the original daughter cell had grown into an opaque cell and the original mother cell had generated a second opaque daughter cell at the opposite cell pole, plus two more evaginations, one at either pole. Between 4.5 and $6 \mathrm{~h}$, most of the new daughter cells generated by the original mother cell and the initial daughter cells exhibited a phenotype which was intermediate between the round white cell and the large asymmetric bean-shaped opaque cell. By $9 \mathrm{~h}$, the microcolony appeared as an inner core of opaque cells surrounded by cells of intermediate phenotype and phenotypically white cells at the microcolony edge. This general scenario, including bipolar budding, was observed during development of the majority of more than 100 microcolonies generated from single opaque cells at $37^{\circ} \mathrm{C}$.

In a less common scenario (Fig. $6 b$ ) an existing evagination grew into a white cell prior to $5 \mathrm{~h}$ of incubation, and all subsequent daughter cells generated from the original mother cell and daughter cells were white. By $9 \mathrm{~h}$, the microcolony consisted of the original opaque cell surrounded by a shell of white cells. Again the original opaque cell formed frequent buds at opposing cell poles.

To test the phenotypic stability of cells in a microcolony generated from an opaque cell at $37^{\circ} \mathrm{C}$, a single opaque cell was isolated from an opaque colony at $24^{\circ} \mathrm{C}$, and incubated on agar at $37^{\circ} \mathrm{C}$. When the colony contained roughly $50 \%$ white cells and $50 \%$ opaque cells (after $6 \mathrm{~h}$ ), every cell in the microcolony was separated, plated individually on nutrient agar, photographed, incubated at $24^{\circ} \mathrm{C}$ for $42 \mathrm{~h}$ and assessed for colony phenotype. Of the 27 microcolonies generated from phenotypically opaque cells, $17(77 \%)$ were exclusively opaque and $5(23 \%)$ were primarily white. Of the 29 microcolonies generated from phenotypically white cells, $25(86 \%)$ were exclusively white and $4(14 \%)$ were exclusively opaque. Of four microcolonies generated from cells of intermediate phenotype, three were opaque and one was white. These results suggest a small degree of phenotypic instability in both directions for cells in an early microcolony emanating from an opaque cell at $37^{\circ} \mathrm{C}$.

\section{Discussion}

The difference in the shape of budding cells in the two phases of the white-opaque transition in C. albicans strain WO-1 (Slutsky et al., 1987; Anderson \& Soll, 1987; Anderson et al., 1989, 1990) has provided us with an opportunity to examine high-frequency switching at the cellular level. Our results suggest that both the sequence of events and frequency of the transition differ in the opposing directions. At $24^{\circ} \mathrm{C}$, opaque cells were found to form first-generation daughter cells with the white phenotype, whereas white cells were found to produce elongate, tapered daughter cells reminiscent of early budding cells induced to convert to the hyphal growth form (Buffo et al., 1984; Soll et al., 1985). These elongate, tapered cells then generated opaque cells both laterally and apically. When opaque cells were induced to convert en masse to white colony-forming units by high temperature induction (Rikkerink et al., 1988), the majority generated cells with phenotypes intermediate between the large bean shape of opaque and the small round shape of white.

The results obtained in this study also suggest a degree of phenotypic instability in early divisions following a switch in both the opaque to white and white to opaque directions at $24^{\circ} \mathrm{C}$, and during high-temperature induction of opaque to white. In a few instances at $24^{\circ} \mathrm{C}$, opaque mother cells produced first a white daughter cell which continued to generate white cells, and then an opaque daughter cell which continued to generate opaque cells. Since a reasonable degree of multinucleation exists in an opaque cell population at $24^{\circ} \mathrm{C}$ (Slutsky et al., 1987), it is impossible to distinguish in these cases whether the observed instability is due to a switch in only one of two nuclei, or whether nuclear segregation of the white and opaque trait has occurred at division. Conversely, a few white mother cells at $24^{\circ} \mathrm{C}$ gave rise to the elongate morphology found to precede opaque cell formation, but these elongate daughter cells in turn produced white cells. In a few other cases, white cells at $24^{\circ} \mathrm{C}$ formed elongate daughter cells which gave rise to opaque cells, but the original white mother cell then formed new white daughter cells. Since white cell populations at $24^{\circ} \mathrm{C}$ are almost exclusively uninucleate (Slutsky et al., 1987), these results suggest nuclear segregation of white and opaque at division. When cells were removed from a temperature-induced microcolony of opaque cells after $5 \mathrm{~h}$ at $37^{\circ} \mathrm{C}$, a minority of whiteappearing cells gave rise to opaque colonies. Therefore, both at $24^{\circ} \mathrm{C}$ and $37^{\circ} \mathrm{C}$, cells which have apparently switched at the cellular level may not be fully committed, and are therefore capable of reverting. Since a switch from white to opaque involves several changes in gene expression discernible either by two-dimensional gel 
electrophoresis (Soll et al., 1990), or with antisera generated against opaque cells (Anderson et al., 1990), it is possible that instability may involve incomplete activation of opaque-specific genes. This possibility is now being tested.

In the original descriptions of the white-opaque transition, frequencies of switching at $24^{\circ} \mathrm{C}$ were inferred from plating experiments in which the population of white colony-forming units in mature opaque colonies was measured to be roughly $2 \times 10^{-2}$ and opaque colony-forming units in mature white colonies roughly $3 \times 10^{-3}$ (Slutsky et al., 1987; Anderson \& Soll, 1987). However, these frequencies were poor indicators of the rate of switching because of differences in crowding dominance, cohesion (Kennedy et al., 1988), phenotypic instability and cell size and shape (Slutsky $e t$ al., 1987). Rikkerink et al. (1988) obtained a more direct measure of rate by isolating single cells on agar, then inoculating each agar block supporting a cell into $100 \mu 1$ of nutrient medium. After $24 \mathrm{~h}$ at $25^{\circ} \mathrm{C}$, cells from each microculture were plated on agar and incubated an additional $4 \mathrm{~d}$. By measuring the number of cultures without a switch, they estimated the frequency of switching in the white to opaque direction at $25^{\circ} \mathrm{C}$ to be $10^{-4}$ to $10^{-5}$, and in the opaque to white directions $5 \times$ $10^{-4}$, using the Luria-Delbruck fluctuation formula. Although this method was superior to the original plating experiments (Slutsky et al., 1987; Anderson \& Soll, 1987), it still did not provide a direct measure of rate at the cellular level since it depended upon colony phenotypes many generations after the switching event. For this reason, we have utilized the difference in cellular phenotype and a simple mathematical model to obtain a measure of switching probability at the cellular level. For microcolonies at $24^{\circ} \mathrm{C}$, we have measured the probability $\alpha_{M}$ of a switch in a single generation to be $1.0 \times 10^{-1}$ in the opaque to white direction, and $1.7 \times 10^{-5}$ in the white to opaque direction. The ratio of the two probabilities is 5882 . The expected number of generations, $K$, before a switch from opaque to white was calculated from $\alpha_{M}$ to be 3.4 , and from white to opaque, 15.8. Because switching frequency in the white-opaque transition is affected by several environmental conditions including ultraviolet irradiation (Slutsky et al., 1985; Morrow et al., 1989), temperature (Rikkerink et al., 1988) and $\mathrm{pH}$ (M. S. Bergen and D. R. Soll, unpublished), the probabilities calculated by our model are specific to the conditions of culturing at $24^{\circ} \mathrm{C}$ employed in this study.
The authors wish to thank Dr Jan Schmid for his suggestions on the mathematical model. They are also indebted to S. Swalwell, F. Rogness and $C$. Bucheit for assistance with the figures. This research was supported by grant AI23922 to D. R. S. and a traineeship from grant HD07216 to M. S. B. from the National Institutes of Health.

\section{References}

ANDERson, J. M. \& Soll, D. R. (1987). The unique phenotype of opaque cells in the 'white-opaque transition' in Candida albicans. Journal of Bacteriology 169, 5579-5588.

Anderson, J. M., Cundiff, L., Schnars, B., Gao, M., Mackenzie, I. \& SolL, D. R. (1989). Hypha formation in the white-opaque transition of Candida albicans by ultraviolet irradiation. Infection and Immunity 57, 458-467.

Anderson, J. M., Mrhalik, R. \& Soli, D. R. (1990). Ultrastructure and antigenicity of the unique cell wall 'pimple' of the Candida opaque phenotype. Journal of Bacteriology 172, 224-235.

BEDELL, G. \& SolL, D. R. (1979). The effects of low concentrations of zinc on the growth and dimorphism of Candida albicans: evidence for zinc resistant and zinc sensitive pathways for mycelium formation. Infection and Immunity 26, 348-354.

Buffo, J., Herman, M. \& Soll, D. R. (1984). A characterization of pH-regulated dimorphism in Candida albicans. Mycopathologia 85, 21-30.

Kennedy, M. J., Rogers, A. L., Hanselman, L. A., Soll, D. R. \& YANCEY, R. J. (1988). Variation in adhesion and cell surface hydrophobicity in Candida albicans white and opaque phenotypes. Mycopathologia 102, 149-156.

LEE, K. L., BuCKLeY, H. R. \& CAMPBell, C. C. (1975). An amino acid liquid synthetic medium for development of mycelial and yeast forms of Candida albicans. Sabouraudia 13, 148-153.

Morrow, B., ANDerson, J., Wilson, J. \& Soll, D. R. (1989). Bidirectional stimulation of the white-opaque transition of Candida albicans by ultraviolet irradiation. Journal of General Microbiology 135, 1201-1208.

Pomes, R., Gil, C., Cabetas, M. D. \& Nombela, C. (1987). Variability of colonial morphology in benomyl-induced morphological mutants from Candida albicans. FEMS Microbiology Letters 48, 255-259.

Rikkerink, E. H. A., Magee, B. B. \& Magee, P. T. (1988). Opaquewhite phenotype transition: a programmed morphological transition in Candida albicans. Journal of Bacteriology 170, 895-899.

Slutsky, B., Buffo, J. \& Soll, D. R. (1985). High frequency 'switching' of colony morphology in Candida albicans. Science 230, 666-669.

Slutsky, B., Staebell, M., Anderson, J., Risen, L., Pfaller, M. \& Soll, D. R. (1987). 'White-opaque transition': a second high frequency switching system in Candida albicans. Journal of Bacteriology 169, 189-197.

Soll, D. R., Herman, M. A. \& Staebell, M. A. (1985). The involvement of cell wall expansion in the two modes of mycelium formation of Candida albicans. Journal of General Microbiology 131, 2367-2375.

Soll, D. R., LANGTimm, C. J., MCDowell, J., Hicks, J. \& Galask, R. (1987). High frequency switching in Candida strains isolated from vaginitis patients. Journal of Clinical Microbiology 25, 1611-1622.

Soll, D. R., Staebell, M., Langtimm, C. J., Pfaller, M., Hicks, J. \& RAO, T. V. G. (1988). Multiple Candida strains in the course of a single systemic infection. Journal of Clinical Microbiology 26, 14481459.

Soll, D. R., ANDerson, J. \& Bergen, M. (1990). The developmental biology of the white-opaque transition in Candida albicans. In Candida albicans: Cellular and Molecular Biology. Edited by $\mathbf{R}$. Prasad. Heidelberg: Springer Verlag, in the Press. 